О. В. Штрімайтіс ORCID 0000-0002-1305-2251

О. М. Филипюк ORCID 0000-0002-1907-3408

T. М. Нестерук

ORCID 0000-0002-0447-9026

О. П. Мялюк

ORCID 0000-0002-5090-6607

О. В. Садовник

ORCID 0000-0001-7391-2316

Комунальний заклад вищої освіти «Рівненська медична академія»

Рівненської обласної ради, Рівне

\title{
ВАЖЛИВІСТЬ ВИКОРИСТАННЯ ЕЛЕКТРОННОГО ОСВІТНЬОГО РЕСУРСУ ДЛЯ ЯКІСНОГО ОСВІТНЬОГО ПРОЦЕСУ
}

\author{
O. V. Shtrimaitis, O. M. Fylypiuk, T. M. Nesteruk, O. P. Myalyuk, O. V. Sadovnik \\ Municipal Institution of Higher Education "Rivne Medical Academy” Rivne Regional Council, \\ Rivne

\section{THE IMPORTANCE OF USING ELECTRONIC EDUCATIONAL RESOURCE FOR QUALITY EDUCATIONAL PROCESS}

\begin{abstract}
Анотація. У статті здійснено аналіз структури електронного освітнього ресурсу як інноваційної технології освітнього процесу та ефективності його використання в КЗВО «Рівненська медична академія».

У результаті дослідження встановлено високу ефективність та продуктивність освітнього процесу із застосуванням електронного освітнього ресурсу. Визначено переваги підготовки студентів до підсумкового тестового контролю з використанням електронного освітнього ресурсу, що доведені вищими показниками якісної успішності здобувачів освіти. Залежно від дисципліни показник якісної успішності студентів був вищий на 16-18 \%.

Структура електронного освітнього ресурсу КЗВО «Рівненська медична академія» представлена у зручній та гнучкій формі, що забезпечує оперативний доступ до інформації, високу оперативність оновлення матеріалів шляхом безперервного впровадження інновацій викладачами та безперешкодного завантаження оновлених матеріалів. Студенти відмічають високу доступність інтерфейсу та інформації навчально-методичних помічників. Електронний освітній ресурс, розміщений у локальній мережі вищого навчального закладу, дозволяє забезпечити здобувачів освіти необхідною інформацією, підвищує рівень та якість освітніх послуг.
\end{abstract}

Ключові слова: електронний освітній ресурс; інноваційні системи; якість освіти; самостійна підготовка студентів; підсумковий тестовий контроль; навчальні матеріали.

\begin{abstract}
The article analyzes the structure of the electronic educational resource, as an innovative technology of the educational process. And the effectiveness of it in use at Rivne Medical Academy. The use of electronic educational resource has high efficiency and productivity in the educational process. We determined the advantages to training students for the final test control (FTC) with the use of electronic educational resource, which proved the high quality on students' performance. The qualitative performance of students was $16-18 \%$ higher depending on the discipline.

The structure of the electronic educational resource in Rivne Medical Academy is presented in a convenient and flexible form. It provides rapid access to information, high-speed updating of materials, the continuous introduction of innovations by teachers and unrestricted download of updated materials. In addition, students note the high availability of the interface and information of teaching aids. Eectronic educational resource is located in the local network of higher educational institutions. It allows educators to provide the necessary information, increase the level and quality of educational services.
\end{abstract}

Key words: electronic educational resource; innovative technology; quality of education; independent training of students; final test control; training materials.

Вступ. Збільшення обсягу інформації, що є в широкому доступі, об’єктивно зумовлює необхід- ність модернізації змісту освітніх програм, програм навчальних дисциплін, оновлення форм, методів

(ㄱ О. В. Штрімайтіс, О. М. Филипюк, Т. М. Нестерук та ін. 
i засобів навчання. Це можливо лише за умови впровадження в інноваційний освітній простір електронного освітнього ресурсу (EOP), забезпечення вищих навчальних закладів доступом до глобальних інформаційних ресурсів з використанням високошвидкісних каналів [1].

Оскільки метою інформатизації суспільства $є$ створення гібридного інтелекту всієї цивілізації, здатного передбачати і управляти розвитком людства, важливу роль у даному процесі має виконувати освіта. Ї̈̈ стратегічно важливим завданням $є$ підготовка високопрофесійних кадрів, здатних розвивати нові інформаційні технології та ефективно використовувати їх у професійній діяльності [4].

Електронний освітній ресурс є своєрідним освітнім середовищем. Окрім текстової інформації, він має велику кількість мультимедійного матеріалу, дозволяє працювати з віддаленими ресурсами і швидко переходити до різноманітних частин у межах електронного видання. Основними перевагами EOP є можливість автономної роботи, наочність матеріалу, яка вища, ніж у друкованих виданнях. Ресурс легко змінювати і доповнювати новими матеріалами (особливо це стосується ресурсів, оптимізованих для роботи у мережі «Інтернет»). Упровадження у навчальний процес ЕОР дозволить на належному методичному рівні забезпечити навчальний процес і підвищити ефективність навчання [1].

Важливим елементом освітнього процесу та нині надзвичайно актуальним згідно з Положенням про електронні освітні ресурси, затвердженим наказом Міністерства освіти і науки, молоді та спорту України від 01.10.2012 р. № 1060, є впровадження в інноваційний освітній простір ЕОР «з метою навчально-методичного, науково-методичного та інформаційного забезпечення організації навчально-виховного процесу» [2].

Мета дослідження - аналіз структури ЕОР як інноваційної технології освітнього процесу та ефективності його використання в КЗВО «Рівненська медична академія».

Методи дослідження: емпіричні (експеримент, спостереження), теоретичні (аналіз, узагальнення). Здійснено аналіз теорії і практики використання EOP на кафедрі хіміко-фармацевтичних дисциплін, опитування педагогічного складу кафедри та студенства щодо ефективної співпраці «студент ↔ викладач», порівняння якісної успішності студентів у процесі експерименту.

Результати дослідження. Згідно з Законом України від 05.09.2017 р. № 2145-VII «Про освіту» [3], однією з трьох складових системи забезпечення якості освіти є система забезпечення якості в закладах освіти (внутрішня система забезпечення якості освіти). Вона включає перелік характеристик. У нашому аналізі ми хотіли би приділити увагу сучасним інноваційним методикам в освітньому процесі, що забезпечують реалізацію характеристик:

- забезпечення наявності необхідних ресурсів для організації освітнього процесу, в тому числі для самостійної роботи здобувачів освіти;

- забезпечення наявності інформаційних систем для ефективного управління закладом освіти.

Для реалізації цих складових, на думку педагогічного колективу кафедри та студентів, необхідні:

1. Абсолютна відкритість та доступність викладача у спілкуванні зі студентами. Це на сьогодні $€$ основою студент-орієнтованого підходу і необхідним елементом освітнього процесу в рамках реалізації інтеграції освіти з їі світовими принципами та підходами.

2. Проведення цікавих неординарних заходів у процесі освітнього процесу (проведення конкурсів, індивідуальних науково-дослідних завдань, тематичних брейн-рингів, професійно-зорієнтованих виховних заходів тощо). Це неодмінно спонукає студентів до навчання, формування любові до професії та більш комплексного ставлення до освітнього процесу. Як показала практика, достатньо часто в таких ситуаціях виникає можливість самореалізації студентів з посередньою успішністю (серед призерів та переможців таких заходів далеко не всі студенти були з успішністю «відмінно» чи «добре», але вони настільки добре зуміли себе реалізувати під час виконання таких завдань, що це викликало захоплення і студентів-відмінників, і викладачів). В майбутньому це спонукало студентів до більшої зацікавленості в освітньому процесі.

3. Активне використання сучасних комп’ютерних технологій на заняттях.

4. Використання сучасних інформаційних систем для якісної самостійної підготовки студентів.

У контексті проведеного опитування студентів та педагогів можемо сказати, що, на сьогодні вимагати від студентів конспект лекцій є характеристикою абсолютно несучасного викладача. Сучасному викладачу, який може зацікавити студента викладом та змістом матеріалу на теоретичному занятті, в принципі не потрібно вимагати наявність конспекту. Більше того, присутність/відсутність студента на теоретичному занятті - це його автономне право. Студент, відсутній на занятті, може бути у бібліо- 
теці. Ймовірно, від нього можна очікувати більш глибоких знань. На нашу думку, єдиною спільною вимогою до студентів, що були присутні чи відсутні на лекції, робили нотатки чи ні, $є$ абсолютне володіння темою на практичному занятті. I саме тут приходять на допомогу сучасні інформаційні внутрішні системи. В КЗВО «Рівненська медична академія» $€$ в наявності внутрішній електронний ресурс «Навчальні матеріали» на базі платформи MOODLE, який містить навчально-методичні матеріали $з$ дисциплін. Високу ефективність та продуктивність використання платформи хочемо розглянути на прикладі підготовки студентів до підсумкового тестового контролю (ПТК) знань із дисциплін «Маркетинг у фармації», «Медичне та фармацевтичне товарознавство», «Охорона праці в галузі». Студентів було розділено на 2 групи та запропонований різний підхід до підготовки кон- тролю знань. Учасники освітнього процесу 1 групи, окрім опрацювання теоретичного матеріалу, узагальнення практичних вмінь та навичок, мали змогу готуватися до ПТК шляхом опрацювання бази тестів з дисципліни, розміщеної на ЕОР. Студенти 2 групи готувалися до ПТК без використання тренувальної тестової бази. В результаті проведення ПТК:

- 3 дисципліни «Маркетинг у фармації» якісна успішність студентів 1 групи склала 74 \%, студентів 2 групи - $56 \%$;

- 3 дисципліни «Медичне та фармацевтичне товарознавство» якісна успішність студентів 1 групи склала $83 \%$, студентів 2 групи - $64 \%$;

- 3 дисципліни «Охорона праці в галузі» якісна успішність студентів 1 групи склала $74 \%$, студентів 2 групи - 58 \%. Детально це видно з діаграм, наведених на рисунку 1.

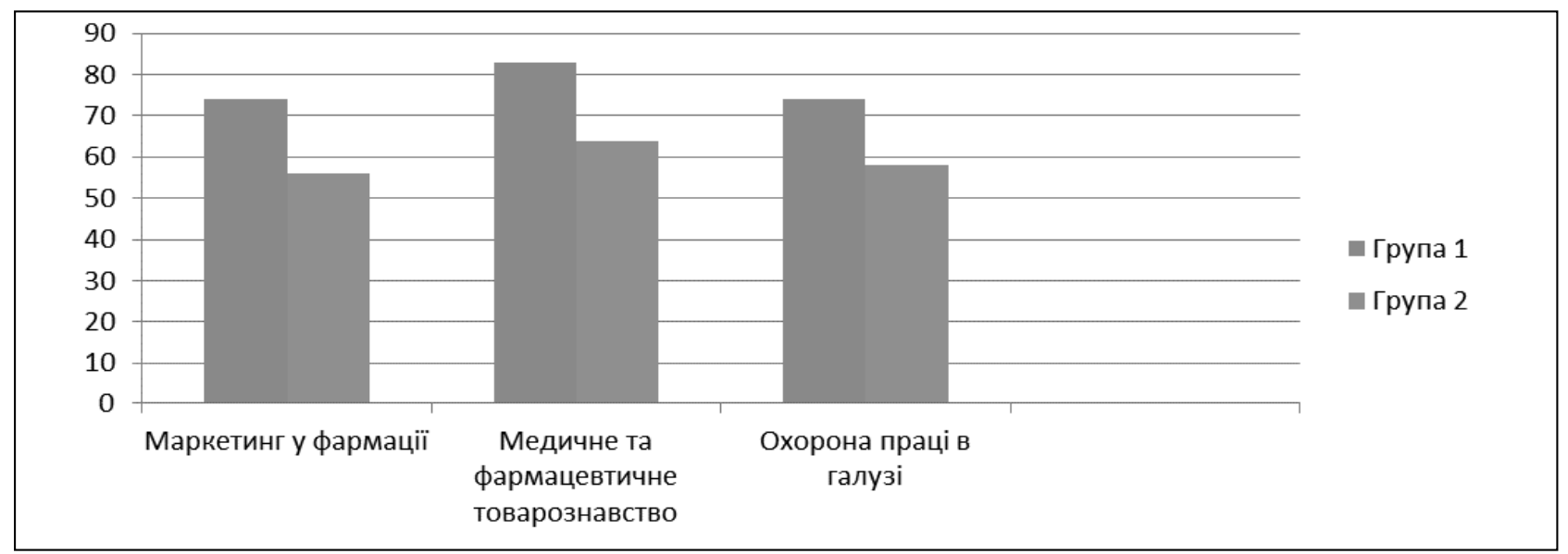

Рис. 1. Результати ПТК студентів.

Таким чином, переваги підготовки студентів до ПТК з використанням ЕОР «Навчальні матеріали» на базі платформи MOODLE:

- достатньо високий відсоток якісної успішності студентів за ПТК;

- можливість аналізу викладачем старань студента в процесі підготовки до написання тестового контролю (як усім відомо, викладач може зайти на сторінку дисципліни і переглянути, хто зі студентів відвідав сторінку, коли і чи пройшов тестовий контроль, а також система продемонструє успішність кожного студента, що робив спробу проконтролювати свої знання);

- $є$ одним із тих моментів, що виступить на захист викладача, якщо студент або його батьки спробують його звинуватити в необ’ єктивності оцінки успішності.

Окрім тематичної тестової бази даних, у системі «MOODLE» інформація стосовно кожної дисциплі- ни, що вивчається, повинна бути подана так, щоб студент міг сформувати абсолютне уявлення про:

- тематику аудиторної та позааудиторної роботи, яка матиме місце у процесі вивчення дисципліни, а також рекомендовану до використання літературу;

- мультимедійний супровід теоретичних занять (текстовий за вибором викладача);

- інструкцію до проведення практичного заняття, з допомогою якої студент може ознайомитися з питаннями $з$ метою самоконтролю при підготовці до практичного заняття, а також опрацювати практичні завдання згідно з наведеними алгоритмами при умові того, що з певних причин на занятті був відсутній.

Надзвичайно актуальним є використання повномасштабного інформаційного забезпечення платформи «Навчальні матеріали» для студентів вечірньої форми навчання. На сьогодні в КЗВО «Рівненська медична академія» на вечірній формі навчаються медсестри - бакалаври та фармацевти - 
бакалаври, які здобувають перший (бакалаврський) рівень вищої освіти на основі диплома молодшого спеціаліста. Ці студенти у своїй переважній більшості поєднують навчання з роботою і частіше відсутні на заняттях, аніж студенти денної форми навчання. I саме використання сучасних інноваційних комп’ютеризованих підходів дає можливість реалізації індивідуалізованого підходу до освітнього процесу кожного студента, який лежить в основі сучасних педагогічних вимог.

Завантаження ЕОР для студентів дало змогу представити навчальний матеріал у зручній та гнучкій формі, забезпечити оперативний доступ до інформації, незалежно від місця знаходження здобувача освіти, забезпечити високу оперативність оновлення матеріалів шляхом безперервного впровадження інновацій викладачами та безперешкодного завантаження оновлених матеріалів. Студенти відмічають високу доступність інтерфейсу та інформації навчально-методичних помічників.

Висновки та перспективи подальших досліджень. 1. Надзвичайно важливим є постійне самовдосконалення викладачів та підвищення вимогливості до себе, опанування новітніх підходів в

\section{Список літератури}

1. Козлов В. Є. Електронні освітні ресурси. Загальні вимоги та методика створення / В. Є. Козлов, О. М. Сальников // Честь і закон. - 2013. - Вип. 1 (44). - С. 73-76. - Режим доступу : file://C:/Users/Admin/AppData/Local/ Packages/Microsoft.MicrosoftEdge_8wekyb3d8bbwe/ TempState/Downloads/Chiz_2013_1_14\%20(1).pdf.

2. Положення про електронні освітні ресурси. - [Затв. наказом Міністерства освіти і науки, молоді та спорту України 01.10.2012 р. № 1060] [Електронний ресурс].

\section{References}

1. Kozlov, V.Ye., \& Salnykov, O.M. (2013). Elektronni osvitni resursy. Zahalni vymohy ta metodyka stvorennia [Electronic educational resources. General requirements and methods of creation]. Chest $i \mathrm{za}-$ kon - Honor and Law, 1 (44), 73-76. Retrieved from: file://C:/Users/Admin/AppData/Local/Packages/Microsoft. MicrosoftEdge_8wekyb3d8bbwe/TempState/Downloads/ Chiz_2013_1_14\%20(1).pdf.

2. (2012). Polozhennia pro elekronni osvitni resursy [Regulations on electronic educational resources. No. 1060]. Retrieved from: http://zakon2.rada.gov.ua/laws/show/ z1695-12 4. освітньому процесі, вдосконалення своєї майстерності і безперервний ріст особистості, як медичного фахівця, так і педагога.

2. На сьогодні у навчальному процесі надзвичайно важливим є використання викладачами сучасних інноваційних комп'ютерних систем і заохочення студентів до цього шляхом проведення роз'яснювальної роботи щодо можливостей використання подібних інноваційних систем. Розміщений у локальній мережі вищого навчального закладу ЕОР дозволяє забезпечити здобувачів вищої освіти необхідною інформацією, підвищує рівень та якість освітніх послуг.

Перспективи подальших досліджень спрямовані на активне впровадження ЕОР у практику освітнього процесу стосовно всіх дисциплін кафедри та постійний аналіз продуктивності використання запропонованих у результаті аналізу педагогічних підходів. Також перспективою є пошук і розробка комплексу умов для розвитку творчого потенціалу студентів та викладачів із значним акцентом на збільшення об’ ємів самостійної роботи студентів, що є актуального вимогою сучасних освітніх програм.

- Режим доступу : http://zakon2.rada.gov.ua/laws/show/ z1695-12 4.

3. Про освіту : Закон України від 05.09.2017 р. № 2145VII [Електронний ресурс]. - Режим доступу : https:// zakon.rada.gov.ua/laws/show/2145-19.

4. Тарнавська Т. В. Сутність інформаційних технологій в освіті / Т. В. Тарнавська // Вісник Чернігівського національного педагогічного університету. Педагогічні науки. - 2013. - Вип. 108 (1). - Режим доступу : http:// nbuv.gov.ua/UJRN/VchdpuP_2013_1_108_31.

3. (2017). Zakon Ukrainy vid 05.09.2017 № 2145-VII "Pro osvitu" [Law of Ukraine of 05.09.2017 "On Education" No. 2145-VII]. Retrieved from: https://zakon.rada.gov.ua/ laws/show/2145-19.

4. Tarnavska, T.V. (2013). Sutnist informatsiinykh tekhnolohii v osviti [The essence of information technology in education]. Visnyk Chernihivskoho natsionalnoho pedahohichnoho universytetu. Pedahohichni nauky Bulletin of Chernihiv National Pedagogical University. Pedagogical Sciences, 108 (1). Retrieved from: http://nbuv. gov.ua/UJRN/VchdpuP_2013_1_108_31.

Отримано 06.03.19

Рекомендовано 12.03.19

Електронна адреса для листування: oksafarm@ukr.net 